\title{
Development and implementation of a methodology for reverse engineering design of Francis turbine runners
}

\author{
Francis tipi su türbini çarkının tersine mühendislik ile tasarımı için bir \\ yöntem geliştirilmesi ve uygulaması
}

\author{
Kutay ÇELEBIOĞLU ${ }^{1 *}$ (D) Alper KAPLAN² \\ 1,2 Hydro Energy Research Center (ETU Hydro), TOBB University of Economics and Technology, Ankara, Turkey.
}

kutaycelebioglu@gmail.com, alperkaplan.ak@gmail.com

Received/Geliș Tarihi: 04.07.2018, Accepted/Kabul Tarihi: 15.11.2018

* Corresponding author/Yazışılan Yazar doi: $10.5505 /$ pajes.2018.43959 Research Article/Araștırma Makalesi

\begin{abstract}
Francis type hydraulic turbine runners have complex blade shapes. Runner blades have three dimensional profiles that direct the incoming flow. In this study, a reverse engineering methodology is developed for the redesign of turbines. Traditional reverse engineering steps are combined with the basics and flow dynamics of hydraulic turbines and applied to two different turbine runners (which have different specific speeds) of two different hydroelectric power plants in operation. The methodology is first verified by application on the first runner and utilized for the redesign of the runner of another power plant. The reasons for the reduced performance of the second runner are examined with the help of the new inverse engineering design methodology and a rehabilitation study is performed. Thus, the runner which only provides 70\% of its installed capacity, is redesigned and can now utilize its full capacity.
\end{abstract}

Keywords: Simulation, Energy efficiency, Hydroturbine

\section{Introduction}

Hydraulic turbines that are used for energy generation in hydroelectric power plants are divided into two groups based on their working principles as reaction and impulse type turbines. Francis turbines are the most common of reaction type because of their wide range of applicability. Their main components are the draft tube, spiral case, stay vanes, guide vanes and the runner as shown in Figure 1.

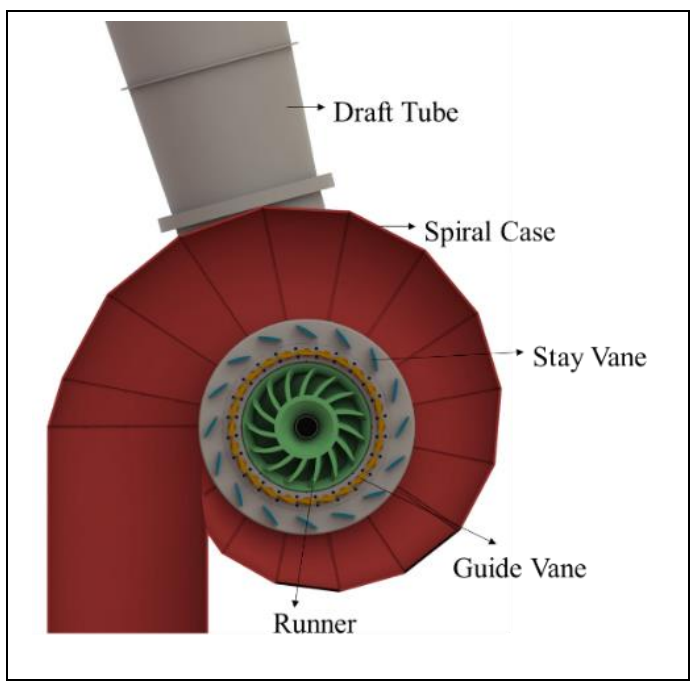

Figure 1: Main components of Francis turbines.
Öz

Francis tipi su türbinlerine ait çark kanatlarının yapısı oldukça karmașıktır. Üc boyutlu profilleri ile gelen akıș yönlendirirler. Bu çalışmada, türbinlerin yeniden tasarımı için bir tersine mühendislik yöntemi geliștirilmiștir. Geleneksel tersine mühendislik yöntemi, hidrolik türbin temel çalışma prensipleri ve akışkanlar mekaniği temelleri ile birleștirilerek iki farklı kullanımda olan santralin türbin çarkına (iki farklı özgül hızı olan) uygulanmıștır. Yöntem, öncelikle bir santrale uygulanarak doğrulanmıs, ardından diğer santralin türbin çarkının yeniden tasarımında kullanılmıstır. İkinci santralin türbin çarkının çalışmasındaki sorunların sebepleri yeni geliştirilen yöntem ile araștırılmıș ve çarkın rehabilitasyonu gerçekleștirilmiștir Kapasitesinin \%70'i verimle çalışan çark, tam kapasite çalışır hale gelmiştir.

Anahtar kelimeler: Simülasyon, Enerji verimi, Su türbini

the turbine through the spiral case, where the flow is distributed uniformly towards the stay vanes. Guide vanes control the discharge, consequently generated power of the turbine. Runner is the part that generates power. It has specifically shaped blades over which water flows. The cross section of the runner blades is usually a thin airfoil structure [1]-[3]. The blades have complex shapes and are iteratively designed with special design software. Especially for the rehabilitation of existing power plants, a reverse engineering design methodology is necessary for the detection and improvement of the performance.

In its most general sense, reverse engineering of shapes is to convert existing parts into engineering designs. Solid models of products cannot be measured with conventional measurement techniques; therefore, they need be obtained with reverse engineering with the help of scanning. Several products can be improved in terms of design or can be manufactured by the utilization of this method [4],[5]. It consists of three main steps: scanning of the product, surface approximation for geometrical modeling and the development of the CAD model. An important part of this process is scanning. The coordinates of the points on the surface are obtained with scanning. Contact and noncontact methods can be used for scanning purposes. Contact type data acquisition methods touch the surface by using a mechanical probe. Light, sound or magnetic fields are used in non-contact type of scanning. The information on the coordinates is obtained by round trip time of the beam which is transmitted from the surface. The scanning method that is going to be used is selected per the complexity of the surface 
that is going to be scanned [6]-[8]. Free formed surfaces are fit to point cloud data that is obtained from scanning in order to develop a solid model. The surfaces are generated using two different methods: curve method and surface method. The construction curves are primarily obtained from point cloud and then free formed surfaces are generated along with construction curves. The surface is directly generated from the measurements in the surface method [5],[9].

Lin et al [10], developed a reverse engineering methodology to meet the customized artificial joint design and to decrease the production cycle and cost. Researchers, first, design a method to get better data points and to deal with cloud data. After organizing the cloud data, free form surfaces are constructed by the data points using the reverse engineering software. With this study, data base of different kinds of prosthesis free form surfaces are obtained through reverse engineering.

Garcia et al [11], developed a geometry reconstruction method for Francis turbine components with reverse engineering approach. To obtain a model, CAD model techniques like basic metrology, surface scanning, 3D digitalization and development of molds are used. The results are compared with assembly drawing values. For spiral case, as the results are not coupled perfectly, linear, exponential and logarithmic functions are tested to eliminate wrong values. With this way, results are refined and maximum error is measured as $1.92 \%$. For draft tube, the dimensions are compared with prototype and error is measured as $0.08 \%$. The covers and fixed blades are modeled from drawings. For obtain the shape of the fluid zone in the runner, low density polyurethane molds were made. Then it is digitalized using a 3D scanner. Computational fluid dynamics analysis and mechanical analysis are performed after the reconstruction of the geometry.

Francis type hydraulic turbine runners have complex blade shapes which should be designed with special design software, based on the solution of three dimensional Navier-Stokes equations. Runner blades have rotational and three dimensional profiles to direct the incoming flow and to provide the best possible efficiency and performance. It is necessary to develop a reverse engineering design methodology for specifically the redesign of the turbines for the rehabilitation of existing hydroelectric power plants. In addition to traditional reverse engineering methodology, it is also important to be able to obtain analyzable blade geometry from the solid model and to determine the blade design parameters from the existing turbines. In this study, a reverse engineering methodology is developed for the redesign of turbines for the rehabilitation of existing power plants. Traditional reverse engineering steps are combined with the basics and flow dynamics of hydraulic turbines and applied to two different turbine runners (which have different specific speeds) of two different hydroelectric power plants in operation. The methodology is first verified by application on the first runner (the turbine of BUSKI HEPP in Turkey) and utilized for the redesign of the runner of another power plant (Kahta HEPP). The reasons for the reduced performance are examined considering the new inverse engineering design methodology and a rehabilitation study is performed to increase the performance.

\section{Reverse engineering design methodology}

The basics of the methodology are shown in Figure 2. The methodology is especially important for the redesign of existing turbine runners that are already in use in actual hydroelectric power plants. The existing runner geometries are scanned and converted into analyzable CAD models. In addition to traditional reverse engineering steps, blade design parameters are also determined to obtain analyzable blade geometries from the solid model.

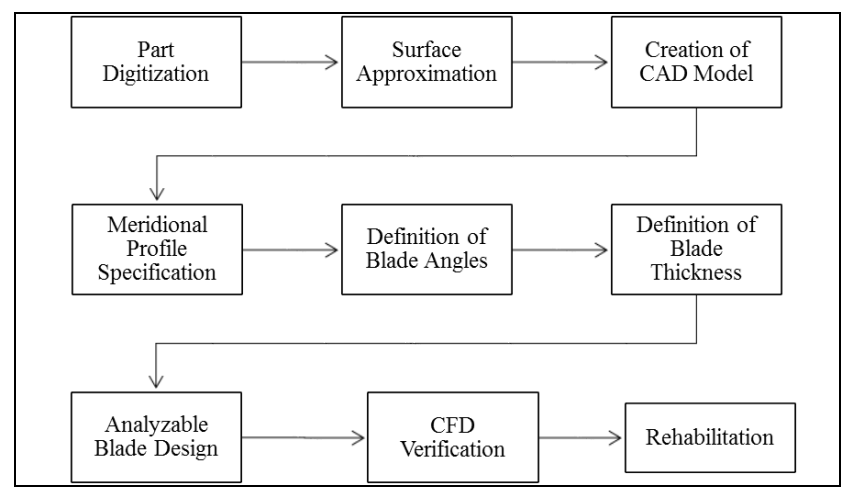

Figure 2: Steps of reverse engineering design methodology.

As shown in Figure 2, the first step in the method is digitization of the parts. Primary purpose of this process is to obtain point cloud data of the blade to be able to generate the CAD model of the turbine runner geometry. Tactile and non-contact methods can be used in this process depending on the arrangement of the blades and the complexity of the blade geometry. Noise-related problems must be solved and the number of points should be reduced before surface generation. The surfaces are generated using the measurements, directly. After the surfaces are generated using the point cloud data, the solid model of the runner is generated. The solid model of one of the blades is formed and the blade profile is reflected to different sections to form the final CAD model for the whole blade.

Determination of the blade design parameters is a vital part of the whole process. Meridional contour, blade angles and blade thickness distribution are the design parameters and they are necessary to obtain analyzable blade geometry. ANSYS Bladegen module [12] and SolidWorks software [13] are utilized for the generation of the blade geometry.

Meridional contour is a two-dimensional profile that determines the boundary of the blade geometry and it is defined as the projection of the runner blade profile to the radial plane. Constituents of the meridional contour are hub, shroud and leading edge, trailing edge curves including inlet and outlet diameters. It is a significant parameter for runner design and turbine performance because it contains geometrical descriptions. The components of the meridional contour are shown in Figure 3.

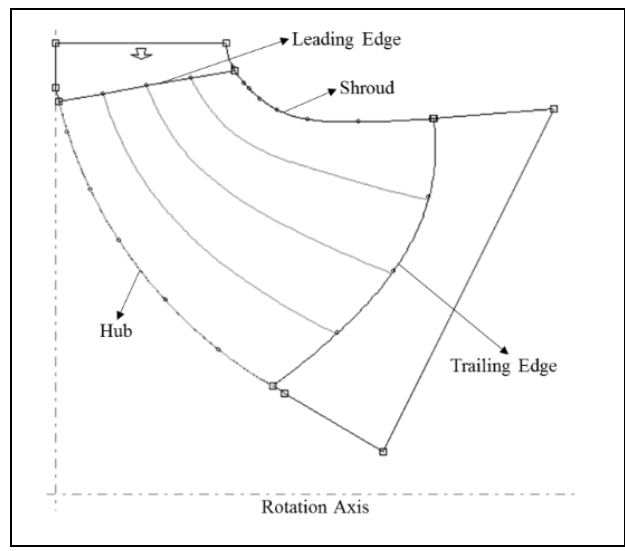

Figure 3: Meridional contour components. 
Meridional contour is determined by projecting the blade geometry to a cross-section which is located at the rotation axis. Leading edge and trailing edge curves are obtained by reflecting on cutting plane of these edges. The curves obtained in different planes are combined within a single plane and the meridional contour is attained by projecting hub and shroud curves to the plane as shown in Figure 4.

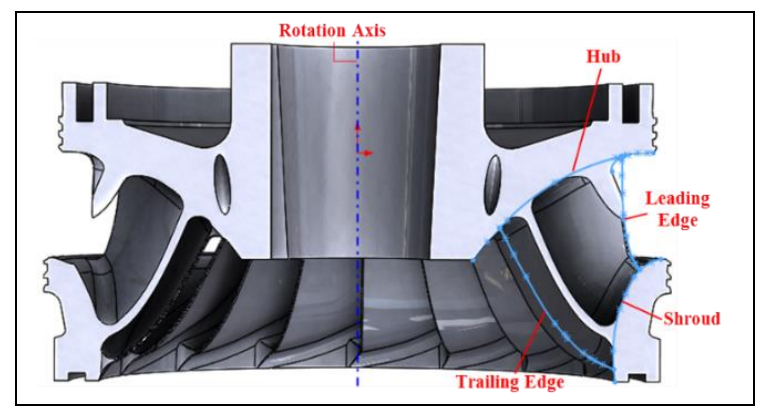

Figure 4: Meridional contour on section plane.

Component curves of the meridional profile are transferred to design program ANSYS Bladegen [12] as point cloud data. Equally spaced span curves used in blade angle definition are identified by Bladegen [12] to facilitate the design as shown in Figure 5. Blade angle distributions and thickness distribution are defined over hub, shroud and span curves from leading edge to trailing edge.

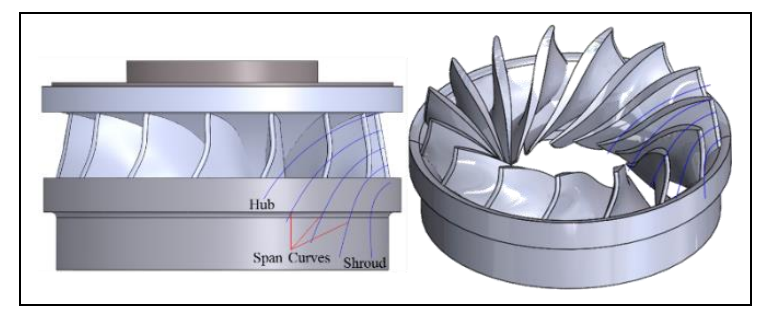

Figure 5: Span curves on runner geometry.

There are two different angle definitions in Bladegen [12], both are determined in camber curve of the blade. Wrap angle, called theta angle, is the position angle in the cylindrical coordinate system, which defines the position of the blade at a given point in the camber line. Metal angle (beta angle) determines the direction of the runner blades at the same point where the wrap angle description is achieved. The positions of the points on the camber curve are calculated by averaging the coordinates of each corresponding points located at pressure and suction sides of the blade.

$$
\begin{gathered}
\mathrm{x}_{\mathrm{i}}^{\mathrm{cc}}=\frac{\mathrm{x}_{\mathrm{i}}^{\mathrm{ps}}+\mathrm{x}_{\mathrm{i}}^{\mathrm{ss}}}{2} \\
\mathrm{y}_{\mathrm{i}}^{\mathrm{cc}}=\frac{\mathrm{y}_{\mathrm{i}}^{\mathrm{ps}}+\mathrm{y}_{\mathrm{i}}^{\mathrm{ss}}}{2} \\
\mathrm{CC}_{\mathrm{i}}=\sqrt{\left(\mathrm{x}_{\mathrm{i}}^{\mathrm{cc}}\right)^{2}+\left(\mathrm{y}_{\mathrm{i}}^{\mathrm{cc}}\right)^{2}+\left(\mathrm{z}_{\mathrm{i}}^{\mathrm{cc}}\right)^{2}} \\
\mathrm{R}_{\mathrm{i}}^{\mathrm{cc}}=\sqrt{\left(\mathrm{x}_{\mathrm{i}}^{\mathrm{cc}}\right)^{2}+\left(\mathrm{y}_{\mathrm{i}}^{\mathrm{cc}}\right)^{2}}
\end{gathered}
$$

Meridional length of a section, $\mathrm{M}_{\mathrm{L}}$, is the distance between leading edge and trailing edge and varies for each section because of the blade structure. Blade leading edge is considered as absolute zero for each section and meridional length of each point on the camber curve is calculated based on absolute zero point.

$$
\begin{gathered}
\mathrm{M}_{\mathrm{i}+1}=\mathrm{M}_{\mathrm{i}}+\sqrt{\left(\mathrm{CC}_{\mathrm{i}+1}\right)^{2}+\left(\mathrm{CC}_{\mathrm{i}}\right)^{2}} \\
i=0, \cdots, L-1 \\
\mathrm{M}_{\mathrm{O}}=0
\end{gathered}
$$

Meridional length is required to be dimensionless in order to use same meridional length definition for each section.

\section{$\% \mathrm{Mi}=\mathrm{MiML} * 100$}

$\% \mathrm{MO}=0$

$$
\% \mathrm{ML}=100
$$

Blade profiles where blade angles are determined are gained by taking sections with span curves from the solid model. The angle between radius axis and the point located on the camber curve is the wrap angle of the point when viewed from hub side. Blade wrap angle of a point on the camber curve is shown in Figure 6.

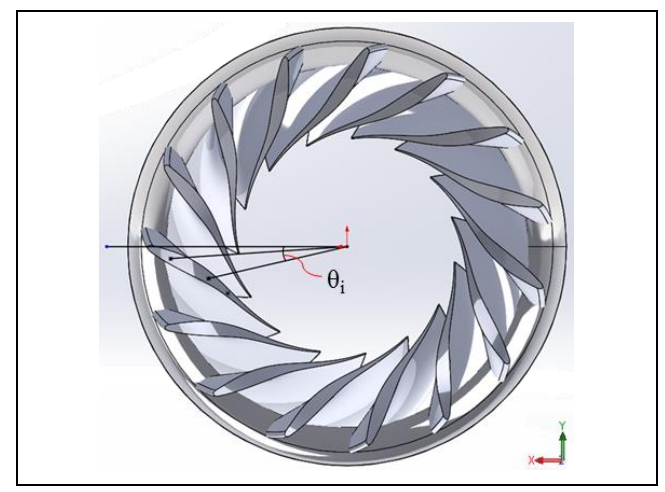

Figure 6: Wrap angle.

Wrap angle is calculated using the distance from rotation axis (x-coordinate) and the distance from radius axis (y-coordinate) as shown in Equation 8.

$$
\theta_{\mathrm{i}}=\tan ^{-1}\left(\frac{\mathrm{y}_{\mathrm{i}}}{\mathrm{x}_{\mathrm{i}}}\right)
$$

Conformal mapping method is used to determine the blade metal angles. The position of a point on the camber curve on conformal mapping is determined by Equation 9. Blade leading edge is considered as absolute zero for each section as it is in the meridional length definition. Figure 7 shows conformal plan of a section.

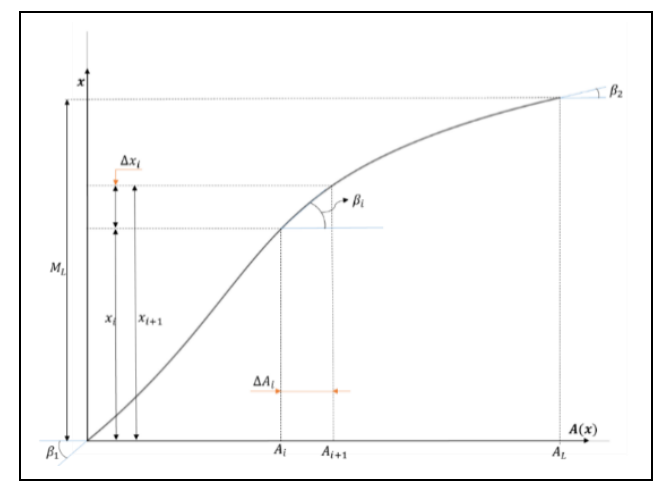

Figure 7: Conformal mapping. 


$$
\begin{gathered}
\Delta A_{i}=\Delta \theta_{i} *\left(\frac{R_{i}+R_{i+1}}{2}\right) \\
A_{O}=0
\end{gathered}
$$

In Figure $7, \beta_{1}$ represents leading edge metal angle, $\beta_{2}$ represents trailing edge metal angle. Metal angle of a point on camber curve, $\beta_{\mathrm{i}}$, is calculated as follows.

$$
\begin{gathered}
\tan \beta_{1}=\left.\frac{\mathrm{dA}(\mathrm{x})}{\mathrm{dx}}\right|_{\mathrm{M}_{\mathrm{O}}} \\
\tan \beta_{2}=\left.\frac{\mathrm{dA}(\mathrm{x})}{\mathrm{dx}}\right|_{\mathrm{M}_{\mathrm{L}}} \\
\tan \beta_{\mathrm{i}}=\frac{\Delta \mathrm{x}_{\mathrm{i}}}{\Delta \mathrm{A}_{\mathrm{i}}}
\end{gathered}
$$

Blade thickness distributions are determined from crosssections which are used in blade angle definitions. Thickness distributions are obtained by the distance between positions of each corresponding points located at pressure side $\left(\mathrm{PS}_{\mathrm{i}}\right)$ and suction side $\left(\mathrm{SS}_{\mathrm{i}}\right)$ of the sections as:

$$
\begin{aligned}
\mathrm{PS}_{\mathrm{i}} & =\sqrt{\left(\mathrm{x}_{\mathrm{i}}^{\mathrm{ps}}\right)^{2}+\left(\mathrm{y}_{\mathrm{i}}^{\mathrm{ps}}\right)^{2}+\left(\mathrm{z}_{\mathrm{i}}^{\mathrm{ps}}\right)^{2}} \\
\mathrm{SS}_{\mathrm{i}} & =\sqrt{\left(\mathrm{x}_{\mathrm{i}}^{\mathrm{ss}}\right)^{2}+\left(\mathrm{y}_{\mathrm{i}}^{\mathrm{ss}}\right)^{2}+\left(\mathrm{z}_{\mathrm{i}}^{\mathrm{ss}}\right)^{2}}
\end{aligned}
$$

The thickness is obtained by Equation 15 for all regions on the sections except for the leading edge and trailing edge regions. Elliptical ratios convenient for blade structure are selected for these regions.

$$
\text { Blade Thickness }=\sqrt{\left(\mathrm{PS}_{\mathrm{i}}\right)^{2}-\left(\mathrm{SS}_{\mathrm{i}}\right)^{2}}
$$

\section{Application of the developed reverse engineering design methodology to turbine runners}

The developed design methodology is first applied to the runner design of a new hydroelectric power plant (Runner 1: Buski HEPP). After its validation, it is also applied to an existing power plant (Runner 2: Kahta HEPP) for design improvements. Kahta HEPP currently utilizes only $70 \%$ of its installed capacity. The reasons of diminished performance are investigated with the new reverse engineering design methodology and the performance is increased with the help of computational fluid dynamics integrated reverse engineering design.

Figure 8 shows the meridional contours which are obtained by projecting the blade geometries to the cross section for the two different runners, after obtaining the runner geometries with the help of laser scanning for Kahta (Runner 1) and solid modeling for Buski (Runner 2) runners.

Point clouds are generated for the leading edge, trailing edge, hub and shroud curves and are transferred to the turbomachinery design software, Ansys Bladegen [12]. Three span-curved meridional profiles are used for each of the runners. The runner geometries are sectioned with span curves to obtain the blade profiles. The angle and thickness definitions are obtained with the help of blade profiles. Equally spaced points are taken from each side (both pressure and suction sides) of the blade profiles. Positions of the points on the camber curve are found out with Equation 4. Non-dimensional meridional lengths are used when angle and thickness distributions are transferred to the design software. The wrap angles are calculated using the coordinates of the points by
Equation 8. The wrap angle distributions for both runner blades are shown in Figure 9.

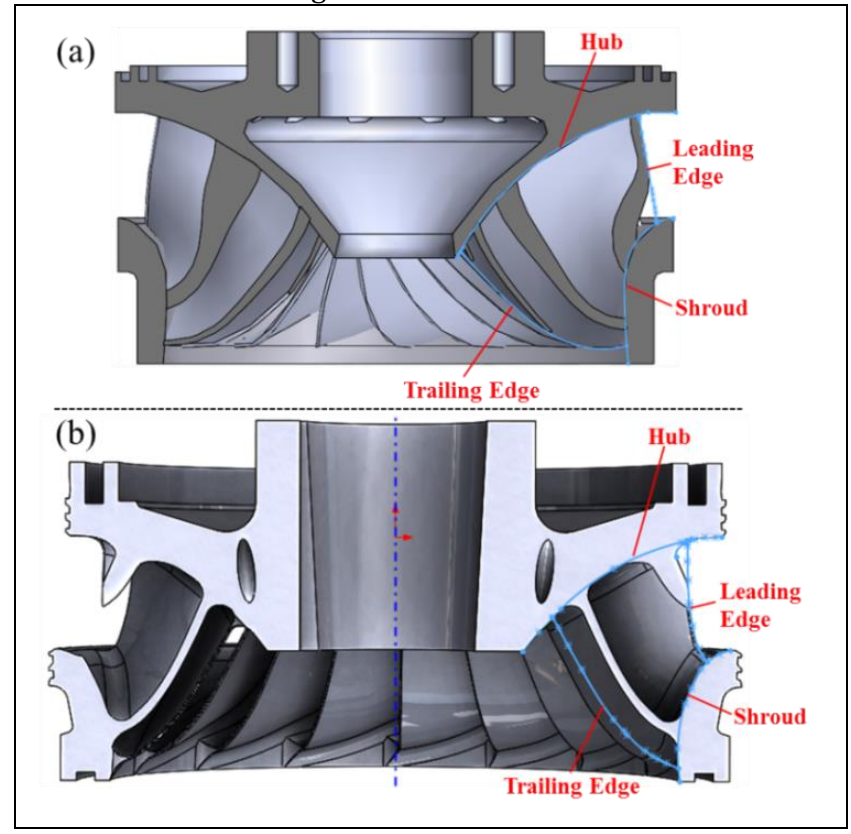

Figure 8: The meridional profiles (a) Runner 1 (b) Runner 2.

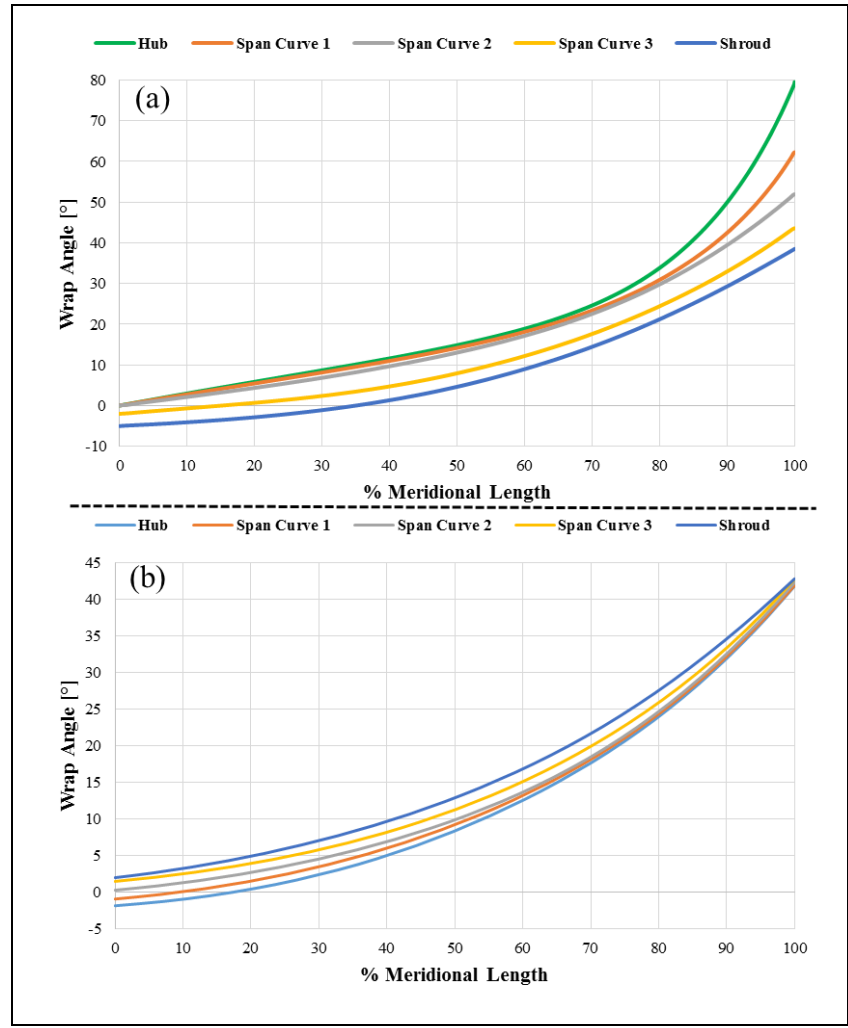

Figure 9: Wrap angle distribution. (a): Runner 1, (b): Runner 2.

Positions of the points on conformal mapping are calculated in accordance with Equation 9 and the metal angle distributions are found out by conformal mapping method which is a function that preserves angles locally [14]. Figure 10 shows the metal angle distributions for the two runners.

Blade thickness distributions are calculated using the distance of the corresponding points located on the pressure and suction sides of the profiles. Thickness calculations for leading edge and 
trailing edge regions are neglected since elliptical ratios are assigned to the leading and trailing edges in the design software. Figure 11 shows the blade thickness distributions.

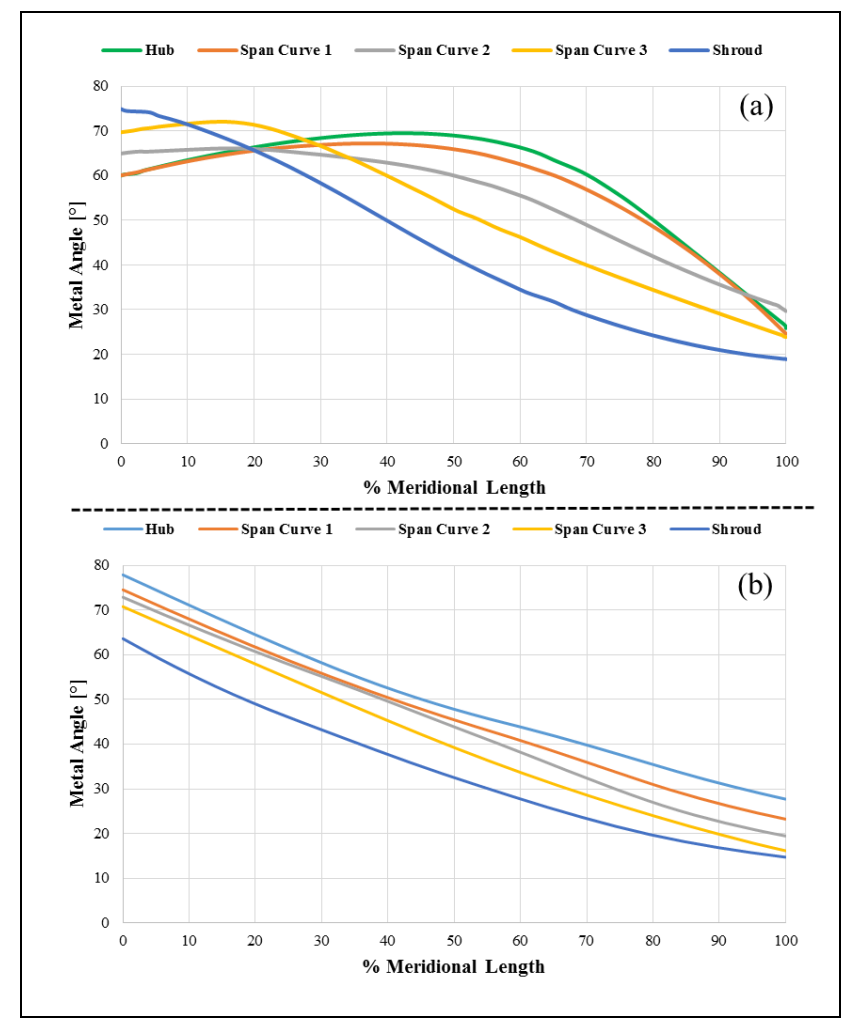

Figure 10: Metal angle distribution. (a): Runner 1, (b): Runner 2 .

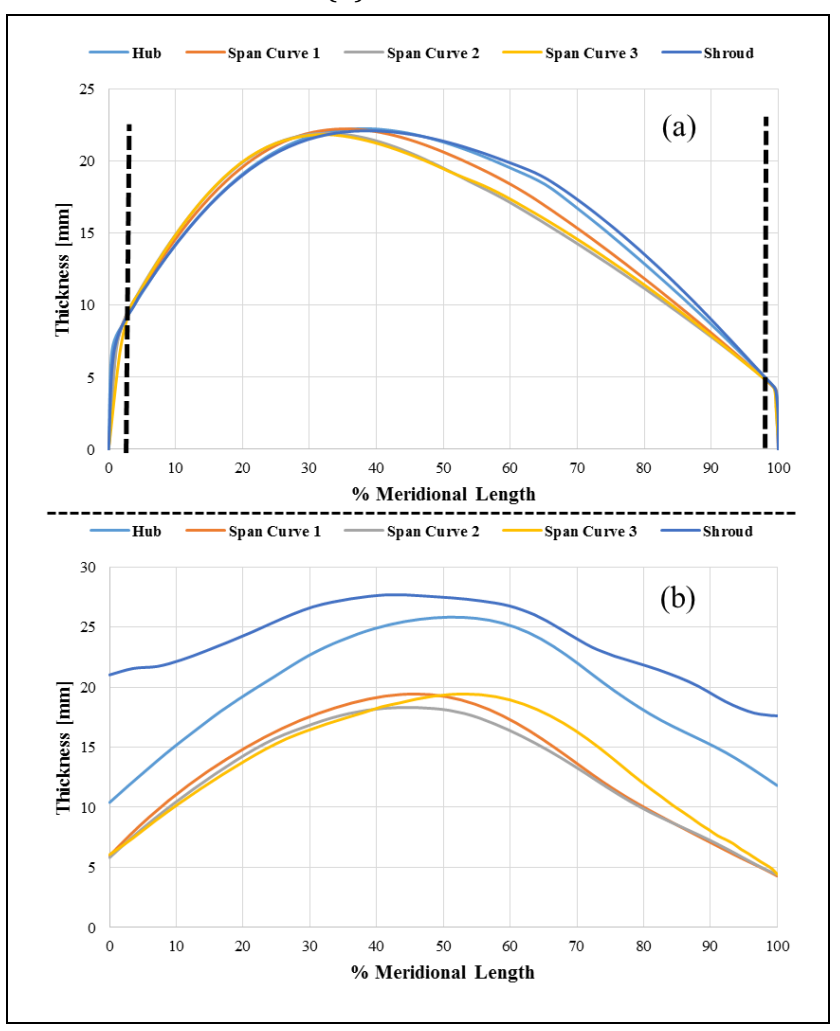

Figure 11: Blade thickness distribution. (a): Runner 1, (b): Runner 2 .
Volumetric comparisons are made for both runners and relative volumetric errors are calculated. Mainly, the volumes of the original geometries and the geometries obtained through the reverse engineering methodology are compared with each other for the two runners. The volumes of the original and reverse engineering geometries are given in Table 1 .

Table 1: Volumes of the original and the reverse engineering geometries.

\begin{tabular}{cccc}
\hline $\begin{array}{c}\text { Runner } \\
\text { Geometry }\end{array}$ & $\begin{array}{c}\text { Volume } \\
{\left[\mathrm{mm}^{3}\right]}\end{array}$ & $\begin{array}{c}\text { Runner } \\
\text { Geometry }\end{array}$ & $\begin{array}{c}\text { Volume } \\
{\left[\mathrm{mm}^{3}\right]}\end{array}$ \\
\hline Runner 1 & 656582.64 & $\begin{array}{c}\text { Runner 2 } \\
\text { Original } \\
\text { Original }\end{array}$ & 616432.38 \\
$\begin{array}{c}\text { Runner 1 } \\
\text { Reverse }\end{array}$ & 652997.70 & $\begin{array}{c}\text { Reverse } \\
\text { Engineering }\end{array}$ & 585376.90 \\
Engineering & & Enginering \\
\hline
\end{tabular}

The relative error for the total volume of the first runner is 0.55 $\%$, whereas it is $5.04 \%$ for the second runner when the reverse engineering geometries are compared with the original ones. The reverse engineering methodology is applied to the laser scanned geometry of the second runner (Kahta HEPP) since no solid model was available for the actual runner. However, the first runner is a new design and its solid model is available (designed by our group previously [15]). Therefore, there are regions of welding especially on the hub and shroud parts of the second turbine runner, as shown in Figure 11, which makes the volumetric relative error higher for the second runner geometry. The reverse engineering geometries that are almost exactly the same with the originals are shown in Figures 12 and 13 for Runner 1 and Runner 2, respectively.

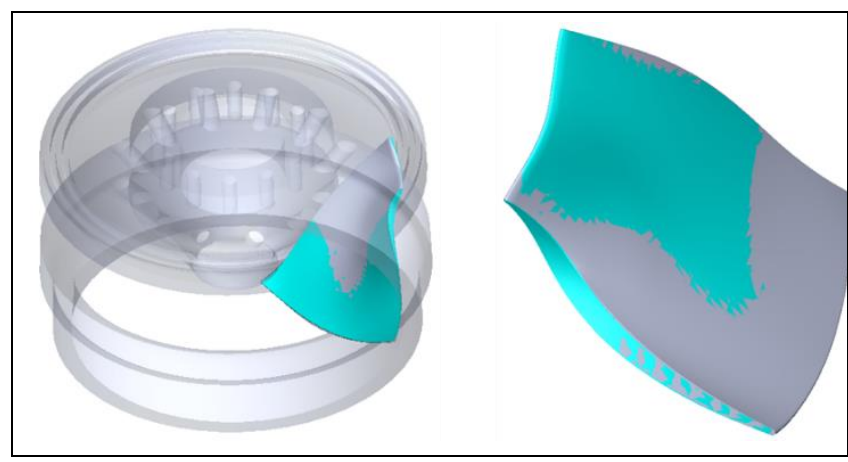

Figure 12: Runner 1 blade geometry.

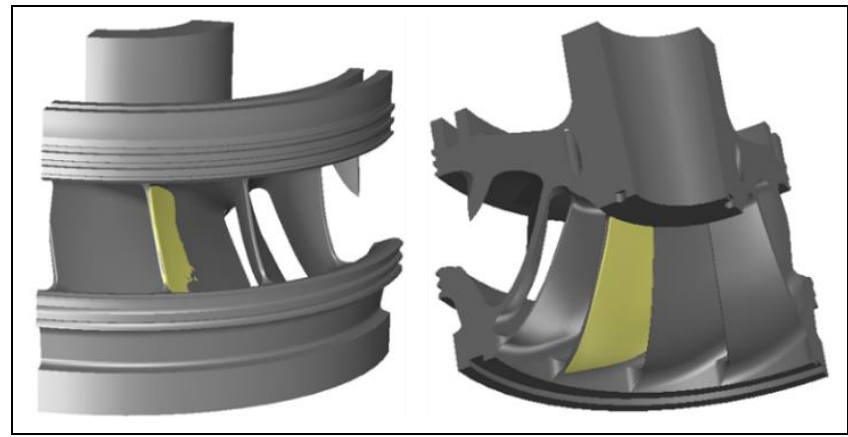

Figure 13: Runner 2 blade geometry.

\section{Computational fluid dynamics analysis of the reverse engineering geometries}

Once, it is determined that the reverse engineering blade geometries reflect the properties of the original geometries, CFD analysis of the turbines are performed for performance 
evaluation. Ansys CFX solver [16] is used for the computational fluid dynamics analyses. Total pressure inlet and mass flow outlet boundary conditions are used. Through CFD analyses, it is verified that the hydraulic performance results of the actual power plants are duplicated. After making sure that the geometries and the performance results are the same with the actual cases, the next step is the redesign of the runner for improved performance.

The first runner (Buski HEPP) has a head of 78m, a flow rate of $2 \mathrm{~m}^{3} / \mathrm{s}$ and an efficiency of $96.32 \%$. The second runner (Kahta HEPP) has a head, discharge and power of $125 \mathrm{~m}$, $3.25 \mathrm{~m}^{3} / \mathrm{s}$ and $3500 \mathrm{~kW}$, respectively.

The flow over Francis turbine blades is complex and three dimensional due to the complexity of the geometry. The Reynolds number for the flow over the blades is very high. To perform the CFD analyses of the geometries, three dimensional Reynolds averaged Navier Stokes equations are solved using k? ?turbulence modeling. Finite volume approach is utilized. First order upwind method and high resolution schemes are used for space discretization. For the preliminary design process, upwinding is selected to reduce the design time; however, for the final designs, high resolution scheme is selected. Unstructured grids are used in the computations. Grid independent results are obtained for each runner design. Figure 14 shows an example grid for the runner. In order to achieve a grid-independent solution, the computational runs are performed for several grids and number of elements.

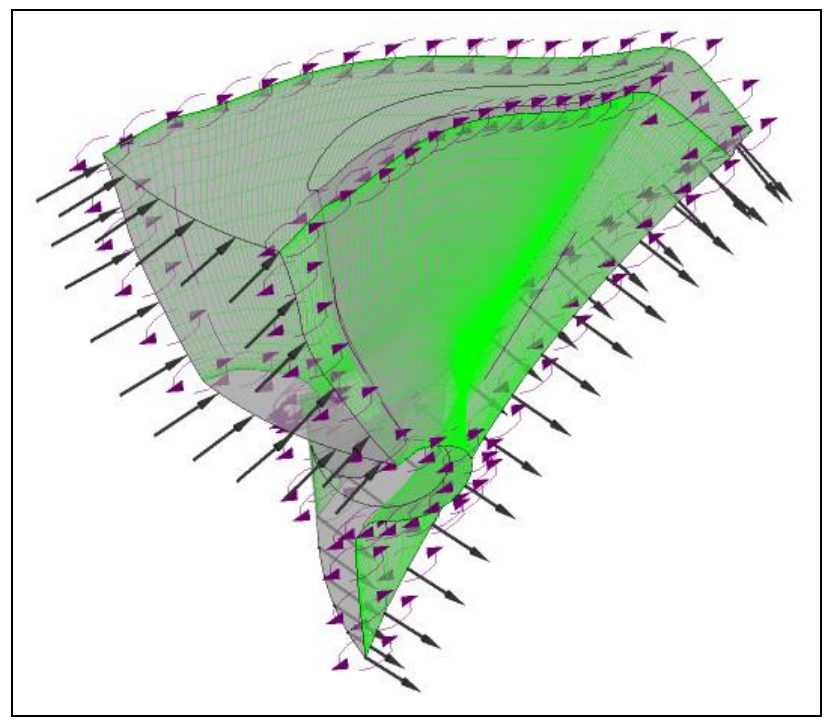

Figure 14: Grid for the runner.

Efficiency and head are used to prove that the solutions are not dependent on the grid. Figure 15 and Figure 16 show the results for efficiency and head for several grids composed of five different numbers of elements.

$y+$ (the non-dimensional height for the first cell) is an important parameter for obtaining accurate solutions. Figure 17 shows y+ values for the blade surface for several grids. The grid with 500,000 elements is used for the rest of the study after careful examination of Figures 15, 16 and 17.

Table 2 shows the results for the CFD analysis of the first runner (Buski HEPP). The analysis results for the original blade geometry and the reverse engineering geometry are shown in Table 2 . There is only a $0.3 \%$ difference in the results for the efficiency.

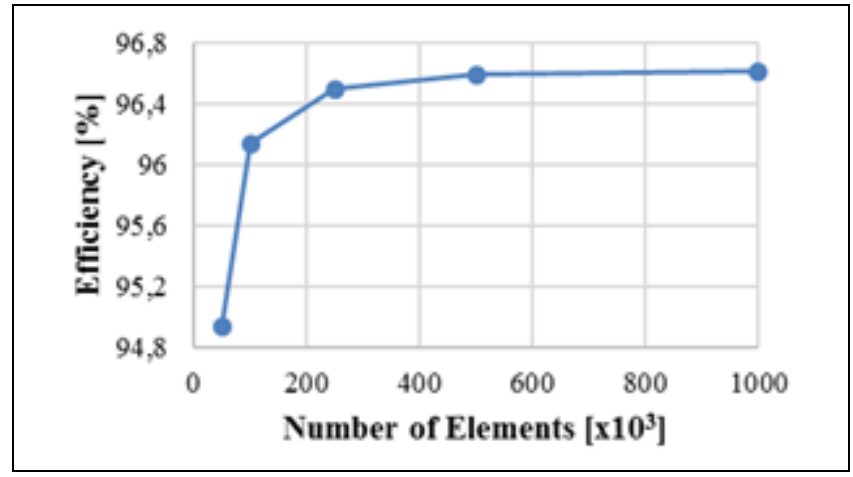

Figure 15: Mesh independency for efficiency.

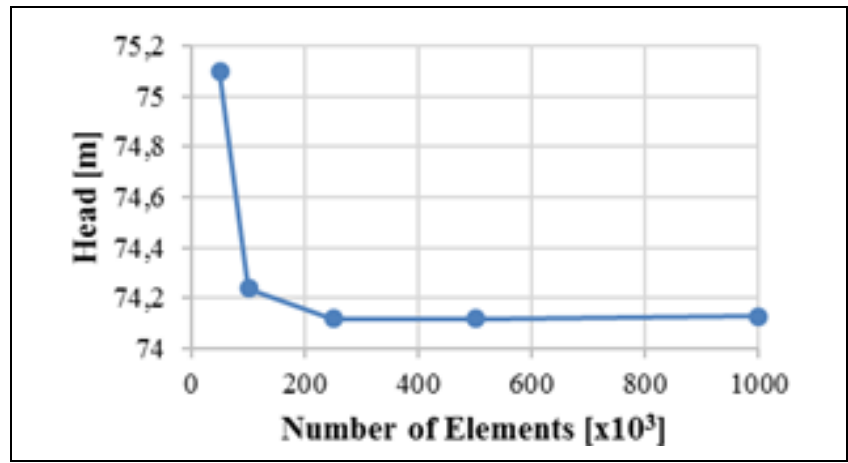

Figure 16: Mesh independency for head.

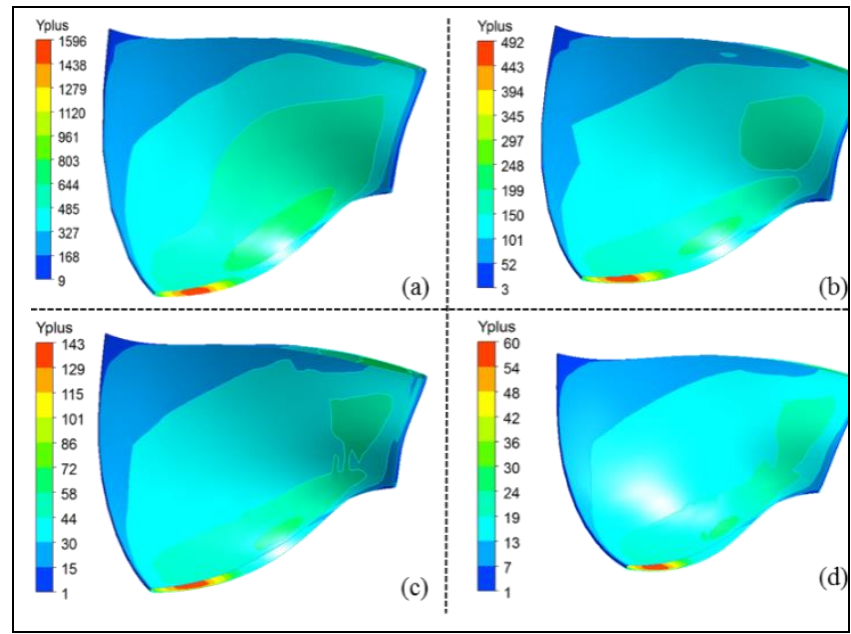

Figure 17: $y^{+}$distributions for. (a): 20x103, (b): 100x103, (c): 250x103, (d): 500x103 number of elements.

Table 1: Runner 1 performance values and comparison.

\begin{tabular}{cccc}
\hline & $\begin{array}{c}\text { Original } \\
\text { Blade }\end{array}$ & $\begin{array}{c}\text { Reverse } \\
\text { Engineering } \\
\text { Blade }\end{array}$ & $\begin{array}{c}\text { Difference } \\
{[\%]}\end{array}$ \\
\hline Discharge $\left[\mathrm{m}^{3} / \mathrm{s}\right]$ & 2.0 & 2.0 & - \\
Head $[\mathrm{m}]$ & 74.36 & 74.19 & 0.23 \\
Power $[\mathrm{kW}]$ & 1404.65 & 1405.91 & 0.09 \\
Efficiency [\%] & 96.32 & 96.61 & 0.30 \\
\hline
\end{tabular}

Blade loadings, pressure and velocity distributions are also compared. When blade loadings on mid-sections are examined, loadings on the reverse engineering blade are like actual blade loadings as it is in Figure 18; however, loadings of the reverse engineering blade are shifted approximately by $3 \mathrm{kPa}$ both on pressure and suction sides. 


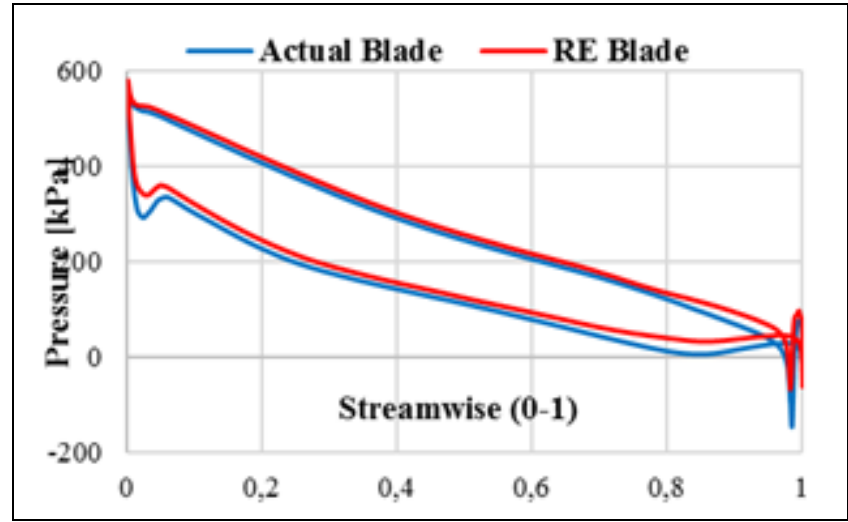

Figure 18: Blade loadings at mid-sections for Runner 1.

In Figure 18; Streamwise $(0-1)$ is the dimensionless blade length, 0 represents leading edge and 1 represents trailing edge of the section.

Figure 19 and Figure 20 show the velocity and pressure distributions on the blades, respectively. As seen from the figures, there is no separation or backflow both in the actual and reverse engineering geometries. Static pressure gradually decreases from the leading to the trailing edges of the blades. Velocity and pressure characteristics of the actual and reverse engineering blades are similar as seen from figures 19 and 20 . The accuracy and applicability of the CFD aided reverse engineering methodology presented in this study is proved with the help of Figures 18, 19 and 20.

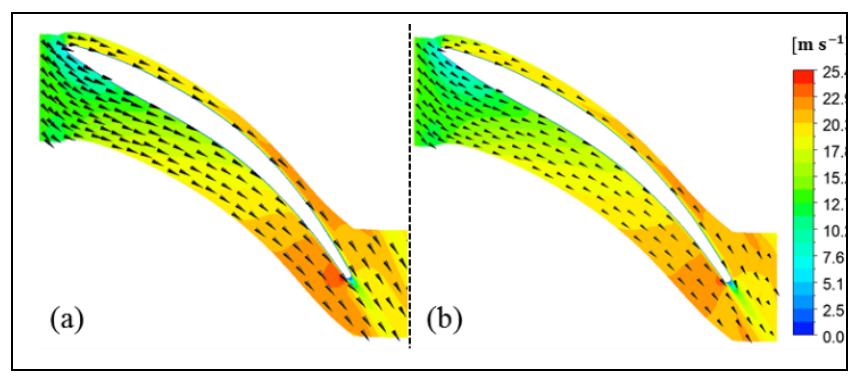

Figure 19: Velocity distribution on (a) actual blade, (b) reverse engineering blade.

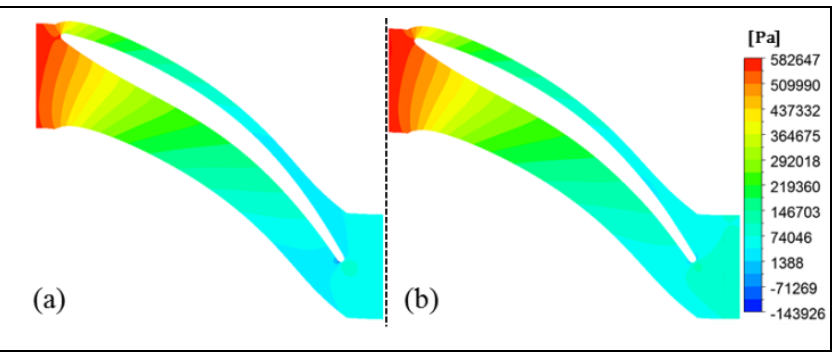

Figure 20: Pressure distribution on, (a): Actual blade, (b): Reverse engineering blade.

\section{Results of the CFD analysis and redesign of runner 2 (Kahta HEPP runner)}

CFD analyses of Kahta HEPP are carried out to find the reasons of diminished performance of the present runner. Preliminary analyses are performed for values between 12 to 24 degrees to find out the angle of attack of the blade with respect to water flow. 16 degrees of inlet flow angle provided $120.6 \mathrm{~m}$ of head and $3485.4 \mathrm{~kW}$ of power, which are close to the performance values of the existing runner of Kahta hydroelectric power plant. When the CFD analysis results are examined, it found out that there is cavitation when the angle of attack is 16 degrees. Water hits the pressure side of the blade instead of the center of the leading edge. Therefore, cavitation starts at the inlet since it is a fore-loaded blade. Flow separation and backflow are detected because of the improper flow angle of the existing blade as seen in Figure 21. Unwanted flow characteristics such as separation and backflow can be seen both in the velocity vectors and pressure distribution over the blade in Figure 21.

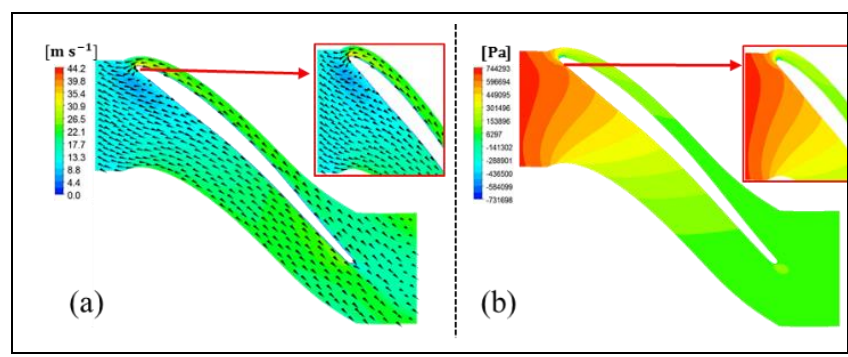

Figure 21(a): Velocity distribution, (b): Pressure distribution for 16 degrees of inlet flow angle at mid-section.

The inlet flow angle is changed to a value to avoid cavitation which is 20 degrees. Figure 22 shows the velocity distribution for 20 degrees of flow angle. As seen in Figure 22, there is no separation or backflow for 20 degrees. Figure 23 shows the pressure distribution over the blade for an inlet flow angle of 20 degrees. Figure 23 shows that the stagnation point is at the center of the leading edge, as desired.

However, this angle only provides $70 \%$ of the installed capacity. The power is $2453.5 \mathrm{~kW}$ for 20 degrees of inlet flow angle, whereas the head value $81.2 \mathrm{~m}$ which means water cannot drop all its energy, there is an excess energy corresponding to $40 \mathrm{~m}$ which is shown in terms of blade loadings in Figure 24.

The physics of the flow in turbines, together with the energy equation, is used to investigate the cause of the diminished performance of the runner. The relationship between power generation and turbine kinematics parameters is shown with energy equation. Velocity components of angular momentum are given in Figure 25 where:

$$
\begin{aligned}
\mathrm{H} \eta & =\frac{\omega}{\mathrm{g} 2 \pi}\left(\Gamma_{1}-\Gamma_{2}\right) \\
\Gamma_{1} & =\pi \mathrm{D}_{1} \mathrm{~V}_{1} \cos \alpha_{1} \\
\Gamma_{2} & =\pi \mathrm{D}_{2} \mathrm{~V}_{2} \cos \alpha_{2}
\end{aligned}
$$

Here, $\mathrm{H}$ is the turbine head in meters, $\eta$ is hydraulic efficiency, $\omega$ is angular velocity in rad/s; $\Gamma_{1}$ is leading edge circulation and $\Gamma_{2}$ is trailing edge circulation, where $V$ is absolute velocity in $\mathrm{m} / \mathrm{s}, D$ is the diameter in meters and $\alpha$ is flow angle.

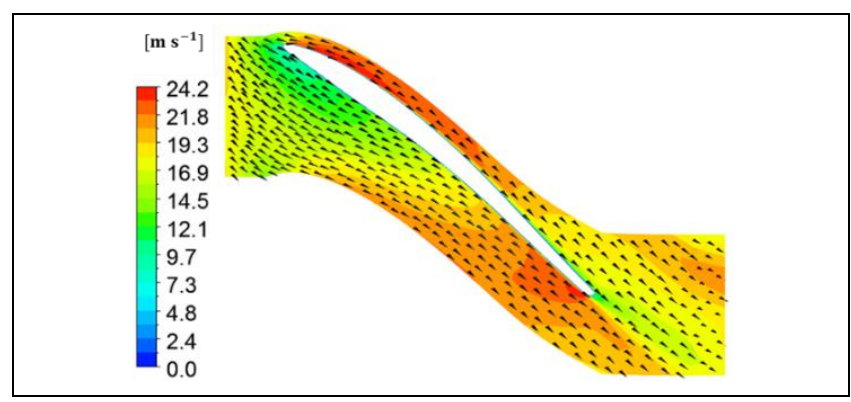

Figure 22: Velocity distribution for 20 degrees of inlet flow. Angle. 


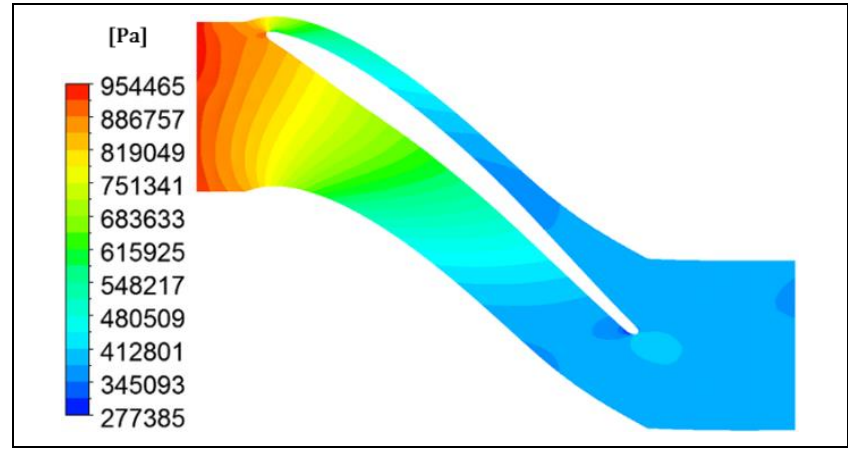

Figure 23: Pressure distribution for 20 degrees of inlet flow angle.

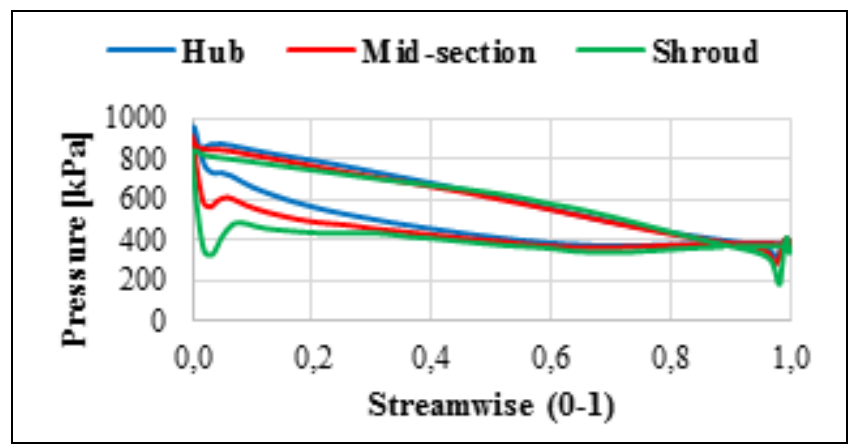

Figure 24: Blade loadings for 20 degrees of inlet flow angle.

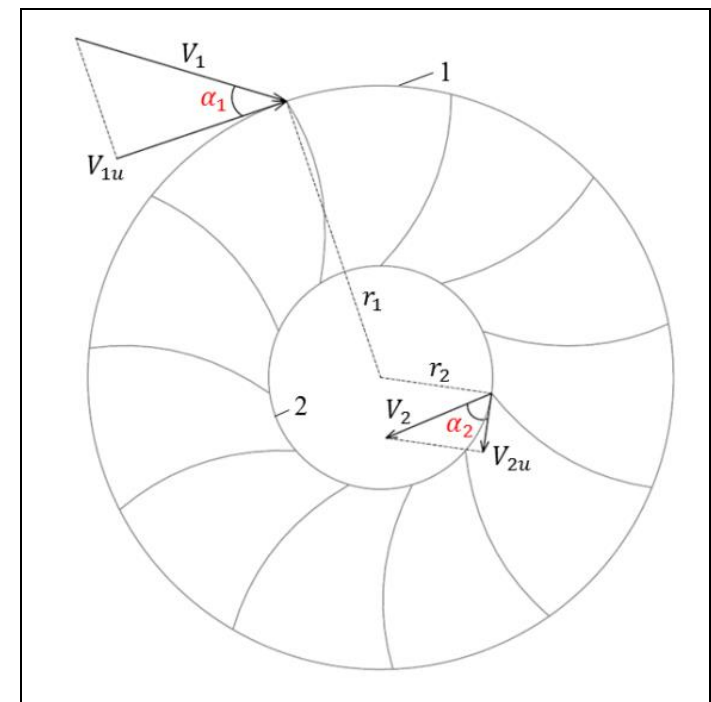

Figure 25: Velocity components of angular momentum on leading edge and trailing edge.

According to energy equation, trailing edge circulation should be as close to zero for high hydraulic efficiency. For this purpose, flow angle of outlet edge should be as far as 90 degrees. When CFD analyses results are examined, outlet flow angle is changed from 41 to 44 degrees per different inlet flow angles. In other words, desired power cannot be produced physically for this geometry.

The basis of the rehabilitation of the runner is setting the trailing edge circulation to zero. For this purpose, firstly, outlet angle is kept close to 90 degrees by changing blade wrap and metal angles gradually. Several modifications are made on the runner and several CFD analyses are performed. The details of the 17 different CFD cases, the geometrical changes made, aim and result in terms of head, power, efficiency and outlet angle of water are shown in Table 3. The blade profiles, thickness, metal and wrap angles of the blades as well as the inlet angle are changed gradually to perform CFD analyses and to observe the effects on performance.

As a result of blade angles changing studies, 107 meters of head and $3242 \mathrm{~kW}$ of power was attained; however, there were still approximately 10 meters of head that cannot be converted to energy. Blade thickness distributions were increased to convert remaining head to energy, as well. In the final design, 121 meters of head, $3540 \mathrm{~kW}$ of power and $96.5 \%$ efficiency is reached, utilizing the total capacity of the water.

Figure 26 shows the pressure and velocity distributions on the final blade. Stagnation point is at the center of the leading edge in the final design and there is no backflow or separation. The new geometry also steers the flow smoothly with accurate inlet and outlet flow angles.

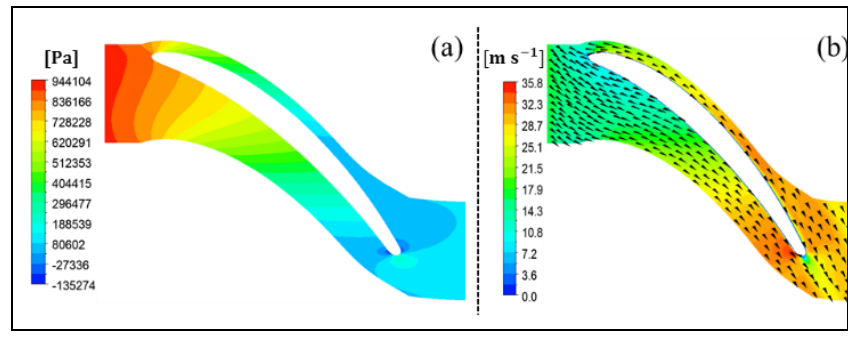

Figure 26(a): Pressure distribution, (b): Velocity distribution of the final design.

\section{Discussion and Conclusions}

In this study, a reverse engineering methodology is developed specifically for the redesign of turbines for the rehabilitation of existing power plants. Traditional reverse engineering steps are combined with the basics and flow dynamics of hydraulic turbines and applied to two different turbine runners (which have different specific speeds) of two different hydroelectric power plants actually in operation. The methodology is first verified by application on the first runner (the turbine of BUSKI HEPP in Turkey), designed previously by our group. According to the results of the verification study, it is observed that the reverse engineering runner has similar performance with the actual runner. The CFD results agree with each other within $0.3 \%$. The developed CFD aided reverse engineering design methodology is proved to be applicable for Francis turbine runners depending on the results of verification case study.

Verified design methodology is applied to the CFD aided analysis, reverse engineering and redesign of the existing runner of another hydroelectric power plant, Kahta HEPP runner which produces only $70 \%$ of installed capacity. The reasons of the diminished performance are determined using the newly developed CFD aided reverse engineering based design methodology and a rehabilitation study is carried out. A new runner geometry that produces $100 \%$ of the installed capacity is designed and computationally tested. The importance of the developed reverse engineering design methodology for rehabilitation studies of Francis turbines is shown with the rehabilitation case study.

\section{Acknowledgment}

The facilities of TOBB ETU Hydro Energy Research Laboratory, financially supported by Ministry of Development, were utilized. 
Table 3: The results of each design.

\begin{tabular}{|c|c|c|c|c|c|c|c|}
\hline Version & Modification & Aim & Result & $\begin{array}{c}\text { Head } \\
(\mathrm{m})\end{array}$ & $\begin{array}{c}\text { Power } \\
(\mathrm{kW})\end{array}$ & $\begin{array}{c}\text { Efficiency } \\
(\%)\end{array}$ & $\begin{array}{l}\text { Oulet flow } \\
\text { angle (o) }\end{array}$ \\
\hline R0 & - & & & 81.2 & 2453.5 & 96.3 & 42.1 \\
\hline R1 & $\begin{array}{l}\text { Leading edge metal } \\
\text { angle is changed to } \\
550\end{array}$ & $\begin{array}{l}\text { To improve inlet } \\
\text { conditions of the } \\
\text { runner }\end{array}$ & $\begin{array}{l}\text { Head and power } \\
\text { increased. Cavitation } \\
\text { is detected because of } \\
\text { the flow separation } \\
\text { near trailing edge. }\end{array}$ & 95.5 & 2882.2 & 94.8 & 72.4 \\
\hline $\mathrm{R} 2$ & $\begin{array}{l}\text { Trailing edge metal } \\
\text { angle is reduced } 40 \text { on } \\
\text { R1 }\end{array}$ & $\begin{array}{c}\text { To prevent } \\
\text { separation and } \\
\text { to improve outlet } \\
\text { flow angle }\end{array}$ & $\begin{array}{l}\text { Flow separation is } \\
\text { reduced and blade } \\
\text { loadings are improved. }\end{array}$ & 101.1 & 3053.7 & 94.8 & 81.5 \\
\hline R3 & $\begin{array}{c}\text { Trailing edge metal } \\
\text { angle is reduced 2o on } \\
\text { R2 }\end{array}$ & $\begin{array}{l}\text { To improve } \\
\text { blade loadings }\end{array}$ & $\begin{array}{l}\text { Blade loadings are } \\
\text { shifted to the outlet } \\
\text { section of the blade. }\end{array}$ & 105.1 & 3171.7 & 94.7 & 87.1 \\
\hline $\mathrm{R} 4$ & $\begin{array}{c}\text { Metal angle } \\
\text { distributions of R3 are } \\
\text { smoothed }\end{array}$ & $\begin{array}{c}\text { To obtain } \\
\text { uniform velocity } \\
\text { distribution }\end{array}$ & $\begin{array}{c}\text { Velocity and pressure } \\
\text { distributions are } \\
\text { improved }\end{array}$ & 106.3 & 3206.6 & 94.6 & 89.6 \\
\hline R5 & $\begin{array}{l}\text { Leading edge metal } \\
\text { angles of R4 are } \\
\text { rearranged except for } \\
\text { hub and shroud }\end{array}$ & $\begin{array}{l}\text { To get a } \\
\text { stagnation point } \\
\text { at the center of } \\
\text { the leading edge } \\
\text { to have a proper } \\
\text { inlet pressure } \\
\text { distribution }\end{array}$ & $\begin{array}{l}\text { Stagnation point is at } \\
\text { the center of the } \\
\text { leading edge }\end{array}$ & 107.4 & 3242.2 & 94.7 & 89.7 \\
\hline R6 & $\begin{array}{l}\text { Camber of R5 is } \\
\text { reduced in all sections } \\
\text { of leading edge }\end{array}$ & $\begin{array}{l}\text { To improve } \\
\text { performance by } \\
\text { narrowing the } \\
\text { flow area }\end{array}$ & $\begin{array}{l}\text { Power increased, } \\
\text { efficiency decreased, } \\
\text { cavitation is detected }\end{array}$ & 119.4 & 3578.5 & 94.0 & 72.2 \\
\hline R7 & $\begin{array}{l}\text { Trailing edge metal } \\
\text { angles of the } \\
\text { midsection and shroud } \\
\text { of R6 are changed }\end{array}$ & $\begin{array}{l}\text { To enhance the } \\
\text { cavitation } \\
\text { performance and } \\
\text { to regulate the } \\
\text { outlet flow }\end{array}$ & $\begin{array}{c}\text { Cavitation } \\
\text { characteristics are } \\
\text { improved, no change } \\
\text { is detected in outlet }\end{array}$ & 116.9 & 3504.9 & 94.1 & 73.2 \\
\hline R8 & $\begin{array}{l}\text { Outlet metal angle is } \\
\text { flattened, blade length } \\
\text { of R7 is increased }\end{array}$ & $\begin{array}{l}\text { To improve } \\
\text { outlet flow } \\
\text { conditions }\end{array}$ & $\begin{array}{l}\text { Slight improvement in } \\
\text { pressure distribution }\end{array}$ & 115.4 & 3496.3 & 95.0 & 87.5 \\
\hline R9 & $\begin{array}{l}\text { Metal angles are } \\
\text { smoothed, inlet flow } \\
\text { angle is set to } 190\end{array}$ & $\begin{array}{l}\text { To reorganize } \\
\text { flow conditions }\end{array}$ & $\begin{array}{l}\text { Inlet blade loadings } \\
\text { are improved, } \\
\text { efficiency decreases, } \\
\text { no change in outlet } \\
\text { pressure distribution }\end{array}$ & 120.1 & 3606.9 & 94.3 & 88.6 \\
\hline R10 & $\begin{array}{l}\text { Blade thickness is } \\
\text { increased } 5 \mathrm{~mm}\end{array}$ & $\begin{array}{l}\text { To convert the } \\
\text { unused head to } \\
\text { energy and to } \\
\text { improve } \\
\text { cavitation } \\
\text { characteristics }\end{array}$ & $\begin{array}{c}\text { Cavitation region is } \\
\text { narrowed }\end{array}$ & 110.9 & 3377.6 & 95.5 & 87.6 \\
\hline R11 & $\begin{array}{c}\text { Inclination of the } \\
\text { metal angle of the } \\
\text { shroud region of R10 } \\
\text { is reduced }\end{array}$ & $\begin{array}{l}\text { To convert more } \\
\text { head to energy }\end{array}$ & $\begin{array}{c}\text { Outlet pressure } \\
\text { distribution goes } \\
\text { worse, cavitation } \\
\text { exists }\end{array}$ & 122.6 & 3716.3 & 95.1 & 88.3 \\
\hline $\mathrm{R} 12$ & $\begin{array}{l}\text { Inclination of the } \\
\text { shroud is taken as the } \\
\text { average of R10 and } \\
\text { R11, outlet metal } \\
\text { angle is smoothed for } \\
\text { the mid-section. }\end{array}$ & $\begin{array}{l}\text { To increase the } \\
\text { curvature and } \\
\text { outlet flow angle }\end{array}$ & $\begin{array}{c}\text { Cavitation } \\
\text { characteristics are } \\
\text { improved }\end{array}$ & 121.3 & 3681.9 & 95.2 & 86.0 \\
\hline R13 & $\begin{array}{l}\text { Metal angle of the hub } \\
\text { of R12 is reduced by } 5 \\
\text { degrees }\end{array}$ & $\begin{array}{l}\text { To smooth } \\
\text { pressure } \\
\text { distribution }\end{array}$ & $\begin{array}{l}\text { A trace of recovery is } \\
\text { obtained at inlet blade } \\
\text { loadings }\end{array}$ & 121.7 & 3700.0 & 95.4 & 89.6 \\
\hline
\end{tabular}


Table 3: Continued : The results of each design.

\begin{tabular}{|c|c|c|c|c|c|c|c|}
\hline R14 & $\begin{array}{l}\text { Inlet metal angle is } \\
\text { decreased by } 10 \\
\text { degrees and } \\
\text { inclination of R13 is } \\
\text { reduced }\end{array}$ & $\begin{array}{c}\text { To prevent } \\
\text { cavitation by } \\
\text { increasing outlet } \\
\text { area between } \\
\text { two blades }\end{array}$ & $\begin{array}{c}\text { Cavitation } \\
\text { characteristics are } \\
\text { improved }\end{array}$ & 120.7 & 3668.4 & 95.5 & 89.3 \\
\hline R15 & $\begin{array}{c}\text { Slight curvature is } \\
\text { defined for all sections } \\
\text { of R14 }\end{array}$ & $\begin{array}{c}\text { To increase } \\
\text { efficiency and to } \\
\text { improve } \\
\text { cavitation } \\
\text { characteristics }\end{array}$ & $\begin{array}{l}\text { Cavitation problem of } \\
\text { the outlet region is } \\
\text { solved; however, flow } \\
\text { separation is detected }\end{array}$ & 121.2 & 3575.8 & 96.2 & 89.9 \\
\hline R16 & $\begin{array}{l}\text { Curvature of R15 is } \\
\text { reduced }\end{array}$ & $\begin{array}{l}\text { To avoid flow } \\
\text { separation }\end{array}$ & $\begin{array}{l}\text { Flow follows the blade } \\
\text { structure; however, } \\
\text { head decreases }\end{array}$ & 118.2 & 3471.4 & 96.4 & 89.5 \\
\hline R17 & $\begin{array}{l}\text { Curvature of the hub } \\
\text { area of R16 is } \\
\text { regulated }\end{array}$ & $\begin{array}{c}\text { To prevent head } \\
\text { loss }\end{array}$ & $\begin{array}{c}\text { Cavitation free blade } \\
\text { with the desired head, } \\
\text { power and separation } \\
\text { characteristics is } \\
\text { obtained }\end{array}$ & 121.2 & 3539.6 & 96.5 & 89.6 \\
\hline
\end{tabular}

\section{References}

[1] Drtina P, Sallaberger M. "Hydraulic turbines-basic principles and state-of-the art computational fluid dynamics applications". Proceedings of the Institution of Mechanical Engineers, Part C: Journal of Mechanical Engineering Science, 213(1), 85-102, 1999.

[2] Krivchenko GI. Hydraulic Machines: Turbines and Pumps., $1^{\text {st }}$ ed. Moscow, Russia, Mir Publishers, 1986.

[3] Alexander KV, Giddens EP, Fuller AM. "Axial-flow turbines for low head microhydro systems". Renewable Energy, 34(1), 35-47, 2009.

[4] Varady T, Martin R R, Coxt J. "Reverse engineering of geometric models-an introduction". Computer Aided Design, 29(4), 255-268, 1997.

[5] Raja V, Fernandes KJ. Reverse Engineering: An Industrial Perspective. $1^{\text {st }}$ ed., London, UK, Springer, 2007.

[6] Motavalli S. "Review of reverse engineering approaches". Computers \& Industrial Engineering, 35(1-2), 25-28, 1998.

[7] Peng Q, Loftus M. A. "New approach to reverse engineering based on vision information". International Journal of Machine Tools \& Manufacture, 38(8), 881-899, 1998.

[8] Lee KH, Park HP. "Automated inspection planning of freeform shape parts by laser scanning". Robotics and Computer Integrated Manufacturing, 16(4), 201-210, 2000.

[9] Farin, G. Curves and Surfaces for Computer-Aided Geometric Design, a Practical Guide. $4^{\text {th }}$ ed., San Diego, CA, USA, Academic Press, 1997.
[10] Lin YP. Wang CT. Dai KR. "Reverse engineering in CAD model reconstruction of customized artificial joint". Medical \& Physics. 27(2), 189-193, 2005.

[11] Garcia R, Boulanger P, Barbosa PJ, Betancur MJ, Quintero $A B$, Castaneda LF, Betancur GGR. "Application of the reverse engineer in the modelling of a francis turbine in a hydroelectric minipower station". 23 ${ }^{\text {rd }}$ ISPE International Conference on CAD/CAM Robotics and Factories of the Future, Bogota, Colombia, 16-18 August 2007.

[12] ANSYS. Bladegen User Manuel, v 15.0, Pennsylvania, USA, 2015.

[13] Dassault Systemes. SolidWorks User Manual. 2014 ed., Massachusets, USA, 2014.

[14] Arfken G. Conformal Mapping in Mathematical Methods for Physicists. $3^{\text {rd }}$ ed., Orlando, FL, Academic Press, 1985.

[15] Ayli E, Kaplan A, Cetinturk H, Kavurmaci B, Demirel G, Celebioglu K, Aradag S. "CFD analysis of 3D flow for 1.4 MW francis turbine and model turbine manufacturing". ASME 2015 International Design Engineering Technical Conferences and Computers and Information in Engineering Conference, Boston MA, USA, 2-5 August 2015.

[16] ANSYS. CFX User Manuel, v 15.0, Pennsylvania, USA 2015. 